\title{
Estimasi Kendaraan Truk Pada Jalan Poros Malino Kabupaten Gowa, Sulawesi Selatan
}

\author{
Mukhtar Lutfie*1,2, Lawalenna Samang ${ }^{2}$, Sakti Adji Adisasmita ${ }^{2}$, M. Isran Ramli ${ }^{2}$ \\ ${ }^{1}$ Jurusan Teknik Sipil, Fakultas Teknik, Universitas Muhammadiyah, Luwuk \\ Jalan KH. Ahmad Dahlan No. 79 Luwuk Banggai \\ ${ }^{2}$ Departemen Teknik Sipil, Fakultas Teknik, Universitas Hasanuddin \\ Jl. Poros Malino km.6, Bontomarannu, Kabupaten Gowa, Sulawesi Selatan 92171 \\ *Email: mukhtarluwuk09@gmail.com
}

DOI: 10.25042/jpe.052019.04

\begin{abstract}
Abstrak
Seiring bertambahnya kendaraan truk mempunyai peran signifikan dalam pengangkutan material bangunan untuk kebutuhan pembangunan infrastruktur di wilayah Sulawesi Selatan. Namun demikian, pengoperasian truk pada jaringan jalan perkotaan untuk kegiatan tersebut, telah membawa isu permasalahan dampak lingkungan berupa peningkatan emisi kendaraan. Sebagai studi terhadap permasalahan ini, maka makalah ini berfokus untuk menganalisis komposisi truk terhadap lalu lintas pada jalan Poros Malino Gowa-Makassar. Studi ini telah melakukan survei pencacahan volume lalu lintas kendaraan truk selama 12 jam dari pukul 06:00 hingga pukul 18:00. Hasil survei tersebut diekstraksi untuk mendapatkan estimasi kendaraan truk dalam sehari. Analisis lebih lanjut terhadap komposisi jenis truk sepanjang hari dilakukan dengan menggunakan pendekatan analisis statistik untuk melihat fenomena dominasi jenis truk yang disurvei. Berdasarkan data di atas dapat diketahui bahwa tingkat komposisi jenis kendaraan truk Engkel Tunggal 2,68,\%, Engkel Ganda 84,00\%, Trintin 0,00\%, Tronton $12,64 \%$, dan Trinton $0,38 \%$. Hasil analisis memperlihatkan bahwa persentase jenis truk tertinggi jumlahnya dan mendominasi truk lainnya adalah kendaraan truk Engkel Ganda.
\end{abstract}

\begin{abstract}
Truck Vehicle Estimation on the Malino Axis Road, Gowa Regency, South Sulawesi. As more trucks have a significant role in transporting building materials for infrastructure development needs in South Sulawesi. However, truck operations on the urban road network for these activities have brought environmental issues of increased vehicle emissions. As a study of this problem, this paper focuses analyzing composition of truck traffic on Poros Malino road Gowa-Makassar. This study has conducted an enumeration survey of traffic volume of truck vehicles for 12 hours from 06:00 to 18:00. The survey results were extracted to obtain the composition of truck vehicles in a day. Further analysis of the composition of truck types throughout the day was conducted using a statistical analysis approach to see the dominant phenomena of the types of trucks surveyed. Based on the above data it can be seen that the level composition of truck type Single Engkel $2.68 \%$, Engkel Double $84.00 \%$, Trintin $0.00 \%$, Tronton $12.64 \%$, and Trinton $0.38 \%$. The analysis shows that the highest percentage of truck types and dominates other trucks is the double crank truck.
\end{abstract}

Kata Kunci: Estimation, Gowa regency, Sulawesi Selatan, truck percentage

\section{Pendahuluan}

Perkembangan transportasi sejalan dengan pertumbuhan penduduk, kenaikan pendapatan, pertumbuhan kepemilikan kendaraan, perluasan kota, serta peningkatan aktifitas ekonomi maupun sosial. Di sisi lain, terdapat kondisi yang tidak sebanding antara laju pertumbuhan kendaraan dengan pertambahan pembangunan jalan di setiap tahunnya, tiap tahun jumlah kendaraan terus bertambah terutama kendaraan berat pengangkut barang dan materil atau kendaraan truk.

Perkembangan transportasi sejalan dengan pertumbuhan penduduk, kenaikan pendapatan, pertumbuhan kepemilikan kendaraan, perluasan kota, serta peningkatan aktifitas ekonomi maupun sosial. Di sisi lain, terdapat kondisi yang tidak sebanding antara laju pertumbuhan kendaraan dengan pertambahan pembangunan jalan di setiap tahunnya, sehingga dapat mengakibatkan 
meningkatnya kecelakaan, kemacetan, dan tundaan di jalan.

Rekomendasi pasca mediasi antara Pemerintah Kota Makassar dan Pemerintah Kabupaten Gowa, seharusnya ditindaklanjuti dengan serius berupa kajian komprehensif terkait operasional truk 10 roda. Kepala Laboratorium Riset Rekayasa Sistem Transportasi Jurusan Teknik Sipil Fakultas Teknik Universitas Hasanuddin, mengungkapkan bahwa sampai saat ini belum ada kajian menyeluruh terkait hal itu. Ia pesimis hal ini bisa dilakukan oleh kedua daerah.

Muatan truk 10 roda memang harus dijadikan pertimbangan evaluasi, terutama dampaknya bagi kemacetan kota dan pertimbangan ekonomi. Makanya, jika hasil kajian usai, maka bisa saja memang ada pengecualian antara truk yang hanya melintas dengan truk yang bolak-balik dalam kota.

Lutfie, dkk. [1] menjelaskan bahwa komposisi truk terhadap volume lalu lintas yang ada cukup kecil: $0,381 \%$ s/d 8,67\%, di mana tingkat distribusi frekuensinya sepanjang hari tidak sama untuk semua jalan arteri di Kota Makassar

Atas dasar itu, maka perlu untuk melakukan penelitian tentang estimasi dan proporsi persentase kendaraan truk di ruas jalan Poros Malino Gowa Sulawesi Selatan.

\section{Metode Penelitian}

\subsection{Lokasi Penelitian}

Data primer diperoleh dari lokasi studi penelitian ini terletak pada ruas jalan Poros Malino Gowa yang terdiri dari dua arah jalan.

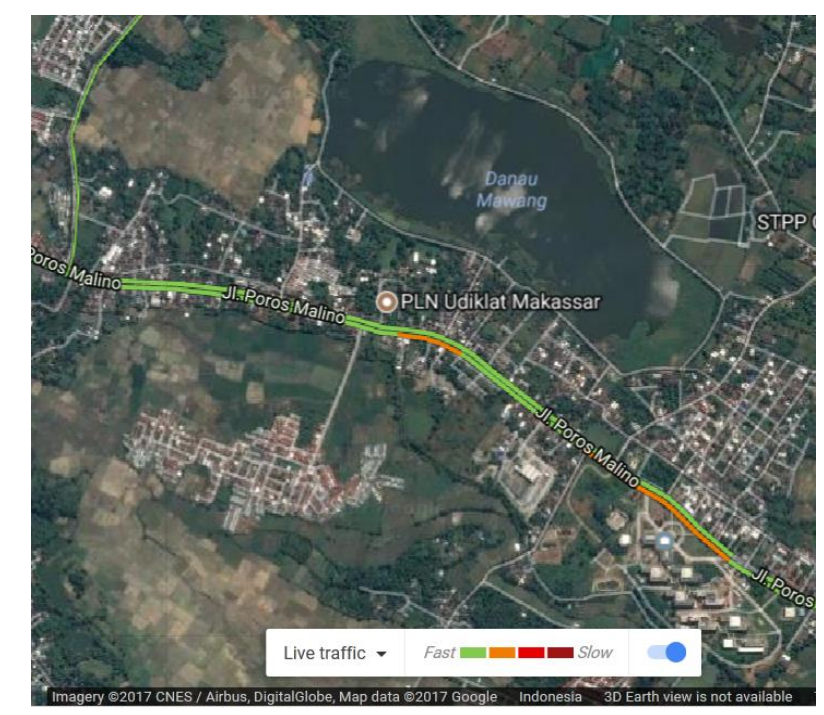

Gambar 1. Lokasi penelitian

Klasifikasi jenis kendaraan truk berdasarkan konfigurasi sumbu yang diteliti pada penelitian ini dapat dilihat pada Tabel 1 berikut:

Tabel 1. Klasifikasi kendaraan truk berdasarkan konfigurasi sumbu

\begin{tabular}{lccl}
\hline $\begin{array}{c}\text { Jenis } \\
\text { Truk }\end{array}$ & $\begin{array}{c}\text { Jumlah } \\
\text { Sumbu }\end{array}$ & $\begin{array}{c}\text { Jumlah } \\
\text { Ban }\end{array}$ & Konfigurasi \\
\hline $\begin{array}{l}\text { Truk Engkel } \\
\text { Tunggal }\end{array}$ & 2 & 4 & $1-1$ \\
$\begin{array}{l}\text { Truk Engkel } \\
\text { Ganda }\end{array}$ & 2 & 6 & $1-2$ \\
Truk Trintin & 3 & 8 & $1.1-2$ \\
Truk Tronton & 3 & 10 & $1-2.2$ \\
Truk Trailer & 4 & 14 & $1.2-2.2$ \\
Engkel & & & \\
Sumber: Wikipedia [2] & &
\end{tabular}

\subsection{Persamaan Persentase}

Persamaan yang digunakan untuk mendapatkan persentase truk adalah sebagai berikut [3]:

$$
\% \text { truk }=\frac{n}{\sum n} \times 100
$$

\subsection{Sitasi dan Referensi}

Sebagai studi awal sebelumnya terhadap permasalahan, telah dilakukan analisis komposisi truk terhadap lalu lintas pada jaringan jalan perkotaan dengan studi kasus di Kota Makassar. Hasil analisis memperlihatkan bahwa komposisi truk terhadap volume lalu lintas yang ada cukup kecil: $\quad 0,381 \% \quad \mathrm{~s} / \mathrm{d} \quad 8,67 \%$, dimana tingkat 
distribusi frekuensinya sepanjang hari tidak sama untuk semua jalan arteri di Kota Makassar.

Penelitian ini dilaksanakan pada bulan September 2016 di ruas Jalan Poros Malino Gowa. Metode yang digunakan dalam penelitian ini adalah metode survey untuk mendapatkan data volume kendaraan truk yang mendominasi saat melintas di ruas jalan. Survey lapangan kinerja lalu lintas mencakup volume kendaraan yang melintas berdasarkan jenis kendaraan truk di ruas jalan tersebut.

Studi ini telah melakukan survei pencacahan volume lalu lintas selama 12 jam dari pukul 06:00 hingga pukul 18:00 pada ruas jalan Poros Malino Gowa. Hasil survei tersebut diekstraksi untuk mendapatkan komposisi jenis kendaraan truk terhadap volume lalu lintas yang ada. Analisis lebih lanjut terhadap komposisi truk sepanjang hari dilakukan dengan menggunakan pendekatan analisis statistik deskriptif untuk melihat fenomena kendaraan truk yang mendominasi sepanjang hari pada ruas jalan perkotaan yang disurvei.

Proses analisa data dilakukan untuk mengetahui volume dan persentase jenis kendaraan truk dan yang dominan melewati ruas jalan Poros Malino pada interval waktu pagi, siang, dan sore dilakukan dengan menggunakan analisis statistik melalui program Mic. Ecxel 2013 for windows.

\section{Hasil dan Pembahasan}

Dari data truk yang diambil, maka dapat diperoleh analisis dan pembahasan sebagai berikut:

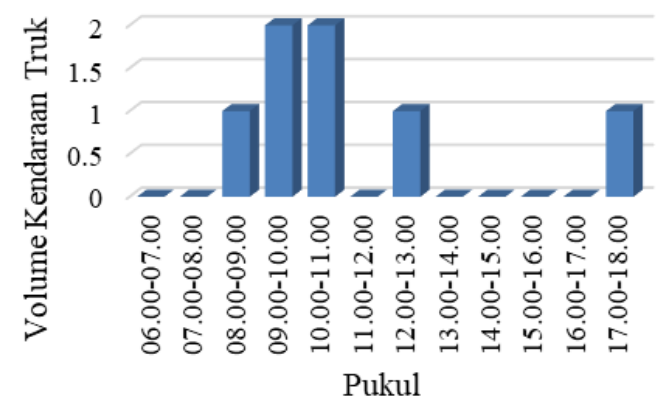

Gambar 2. Volume engkel tunggal
Berdasarkan data di atas dapat diketahui bahwa Volume kendaraan Engkel Tunggal tertinggi yang melewati jalan Poros Malino yaitu pada pukul 09.00 - 11.00 dengan jumlah masingmasing 2 kendaran perjam sedangkan volume terendah pada waktu pagi berada pada pukul 06.00 - 08.00, waktu siang pada pukul $11.00-$ 12.00 dan pukul 13.00 - 14.00 sedangkan pada waktu sore pada pukul $14.00-17.00$ dengan jumlah kendaraan 0 .

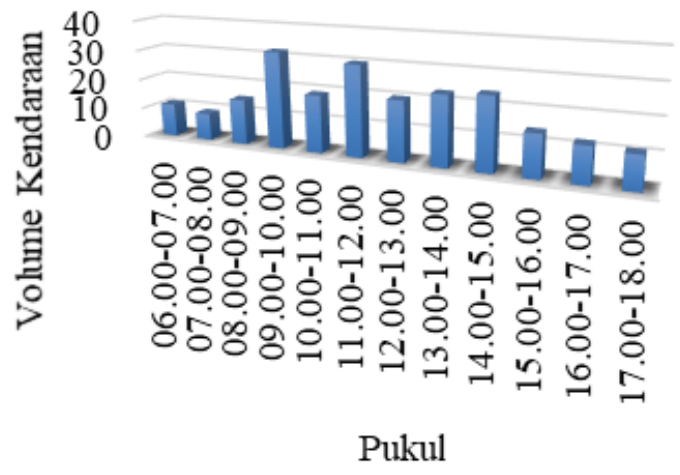

Gambar 3. Volume engkel ganda

Volume kendaraan Engkel Ganda tertinggi yang melewati jalan Poros Malino terletak pada pukul 09.00 - 10.00 dengan jumlah sebanyak 32 kendaraan sedangkan jumlah volume terendah yang berjalan pada waktu pagi pada pukul $07.00-$ 08.00 dengan jumlah 9 kendaraan.

Volume kendaraan Trintin tidak terlihat melewati jalan Poros Malino Gowa-Makassar.

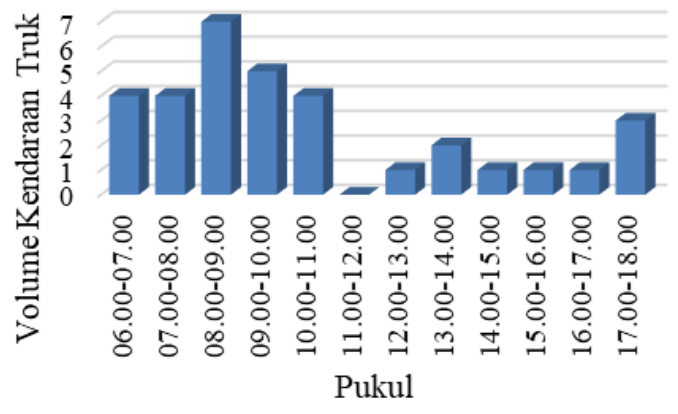

\section{Gambar 4. Volume tronton}

Volume kendaraan Tronton tertinggi yang melewati jalan Poros Malino berada pada pukul $08.00-09.00$ dengan jumlah 7 kendaraan sedangkan volume terendah terjadi pada waktu pagi pukul 11.00 - 12.00 pasalnya tidak ada kendaraan ini yang berjalan pada waktu tersebut. 


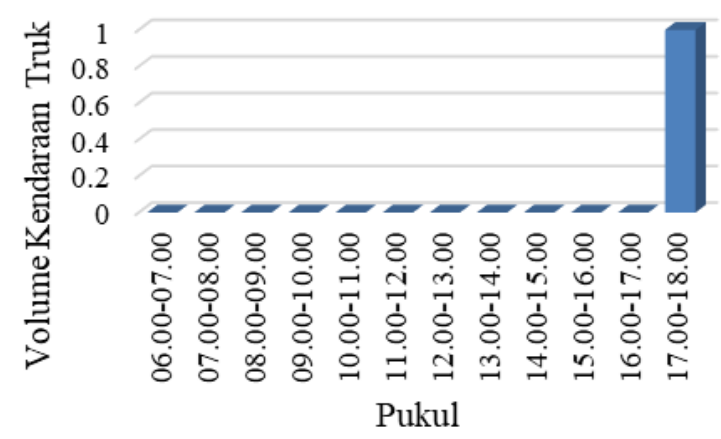

Gambar 5. Volume trinton

Volume kendaraan Trinton yang melewati jalan Poros Malino hanya berjumlah satu buah truk yang berjalan pada pukul 17.00 - 18.00, artinya kendaraan ini tidak terlihat berjalan pada pukul $06.00-17.00$.

Dari empat jenis klasifikasi kendaraan, volume kendaraan truk yang paling dominan adalah Engkel Ganda (84\%), di mana volume kendaraan ini, tertinggi di Jalan Poros Malino Gowa pada waktu pagi pukul 09.00 - 10.00 (39 unit/jam) dan terendah (13 unit/jam) pada waktu pagi pukul $07.00-08.00$.

Analisis estimasi jenis kendaraan truk diambil berdasarkan hasil survei yang telah dihitung volume kendaraan, jumlah persentase kendaraan dan kendaraan truk dominan yang melewati ruas jalan Poros Malino sehingga dapat disajikan dalam bentuk tabel dan chart seperti di bawah ini:

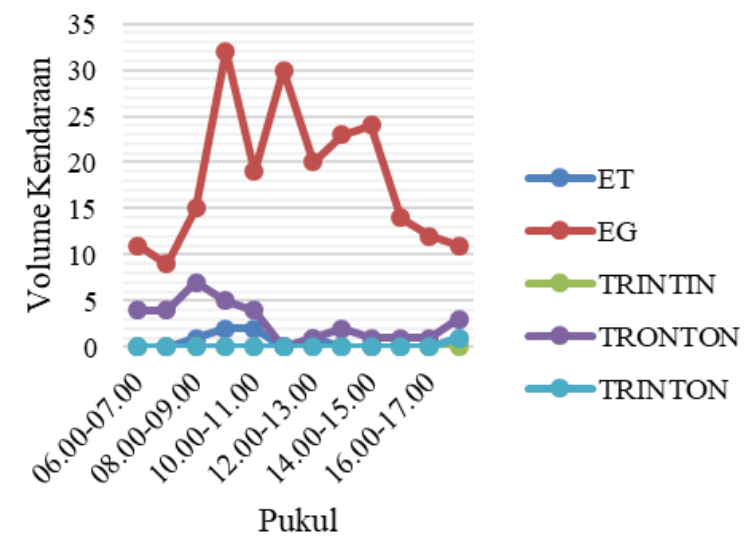

Gambar 6. Volume jenis kendaraan truk

Untuk mengetahui volume jenis kendaraan truk pada ruas jalan Poros Malino, dapat dilihat pada Tabel berikut:
Tabel 2. Volume total jenis kendaraan truk

\begin{tabular}{cc}
\hline Pukul (WITA) & $\begin{array}{c}\text { Volume Kendaraan Per } \\
\text { Jam }\end{array}$ \\
\hline $06.00-07.00$ & 15 \\
$07.00-08.00$ & 13 \\
$08.00-09.00$ & 23 \\
$09.00-10.00$ & 39 \\
$10.00-11.00$ & 25 \\
$11.00-12.00$ & 30 \\
$12.00-13.00$ & 22 \\
$13.00-14.00$ & 25 \\
$14.00-15.00$ & 25 \\
$15.00-16.00$ & 15 \\
$16.00-17.00$ & 13 \\
$17.00-18.00$ & 16 \\
\hline Total & 261 \\
\hline
\end{tabular}

Untuk mengetahui volume total seluruh jenis kendaraan truk pada saat jam tertinggi sampai terendah, dapat dilihat pada Gambar berikut:

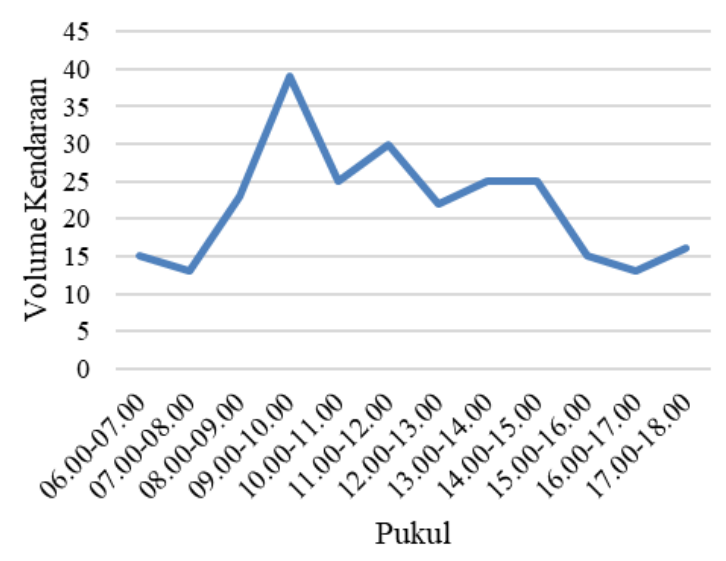

Gambar 7. Volume total seluruh jenis kendaraan truk

Berdasarkan data tersebut, dapat diketahui bahwa volume seluruh kendaraan truk pada ruas jalan Poros Malino tertinggi jumlahnya berada pada pukul 09.00 - 10.00 dengan jumlah 39 kendaraan truk sedangkan volume kendaraan truk dengan jumlah terendah pada waktu pagi pukul 07.00 - 08.00 dan waktu sore pukul $16.00-17.00$ dengan jumlah 13 truk.

Dari hasil pengambilan data, dapat diketahui volume kendaraan truk pada ruas jalan Poros Malino, seperti terlihat pada Tabel berikut: 
Tabel 3. Volume jenis kendaraan truk

\begin{tabular}{lc}
\hline \multicolumn{1}{c}{ Jenis Kendaraan } & $\begin{array}{c}\text { Volume Kendaraan } \\
\text { Perhari }\end{array}$ \\
\hline Engkel Tunggal & 7 \\
Engkel Ganda & 220 \\
Trintin & 0 \\
Tronton & 33 \\
Trinton & 1 \\
\hline Total & 261 \\
\hline
\end{tabular}

Sedangkan dalam bentuk gambar, volume kendaraan truk, dapat dilihat seperti di bawah ini:

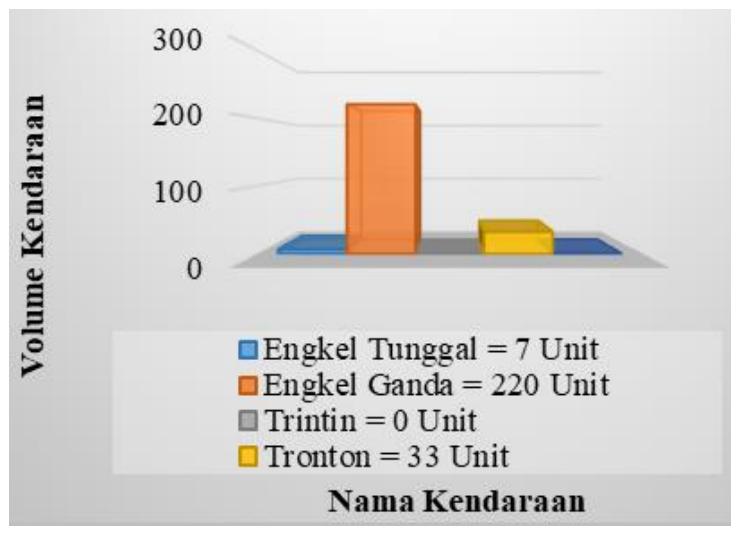

Gambar 8. Volume jenis kendaraan truk

Dari Gambar tersebut memperlihatkan bahwa bahwa kendaraan truk Engkel Ganda mendominasi kendaraan truk lainnya dengan jumlah 220 unit atau sebesar 84\%. Persentase volume truk tertinggi sampai terendah, dapat dilihat pada Gambar berikut:

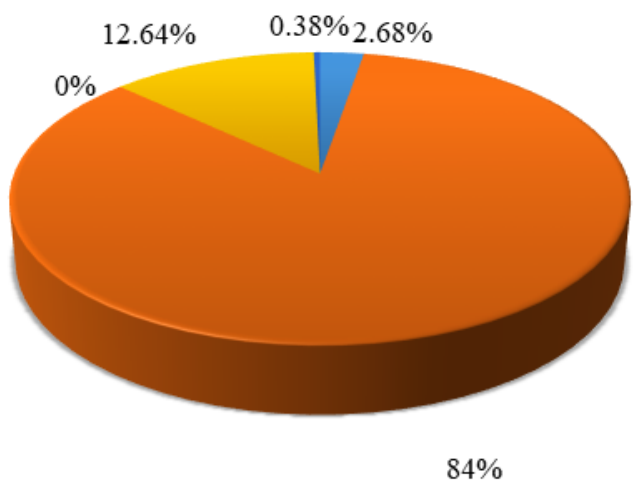

$\square$ Engkel Tunggal $=7$ Unit $\square$ Engkel Ganda $=220$ Unit

$\square$ Trintin $=0$ Unit $\square$ Tronton $=33$ Unit

$\square$ Trinton $=1$ Unit

Gambar 9. Persentase jenis kendaraan truk
Dari Gambar di atas memperlihatkan bahwa bahwa persentase kendaraan Engkel Tunggal sebesar 2,68\%, kendaraan Engkel Ganda sebesar $84 \%$, kendaraan Trintin sebesar $0 \%$, kendaraan Tronton sebesar $12,64 \%$ dan kendaraan Trintin sebesar $0,26 \%$.

Volume kendaraan truk tertinggi jumlahnya pada kendaraan Engkel Ganda Sedangkan kendaraan truk dengan volume terendah terdapat pada kendaraan Trintin.

Untuk mengetahui volume kendaraan Engkel Ganda sebagai kendaraan truk paling dominan pada ruas jalan Poros Malino, dapat dilihat pada Tabel berikut:

Tabel 4. Volume kendaraan engkel ganda

\begin{tabular}{cc}
\hline Pukul (WITA) & $\begin{array}{c}\text { Volume Kendaraan } \\
\text { Engkel Ganda PerJam }\end{array}$ \\
\hline $06.00-07.00$ & 11 \\
$07.00-08.00$ & 9 \\
$08.00-09.00$ & 15 \\
$09.00-10.00$ & 32 \\
$10.00-11.00$ & 19 \\
$11.00-12.00$ & 30 \\
$12.00-13.00$ & 20 \\
$13.00-14.00$ & 23 \\
$14.00-15.00$ & 24 \\
$15.00-16.00$ & 14 \\
$16.00-17.00$ & 12 \\
$17.00-18.00$ & 11 \\
\hline Total & 220 \\
\hline
\end{tabular}

Untuk mengetahui volume kendaraan Engkel Ganda pada saat jam tertinggi sampai terendah, dapat dilihat pada Gambar berikut:

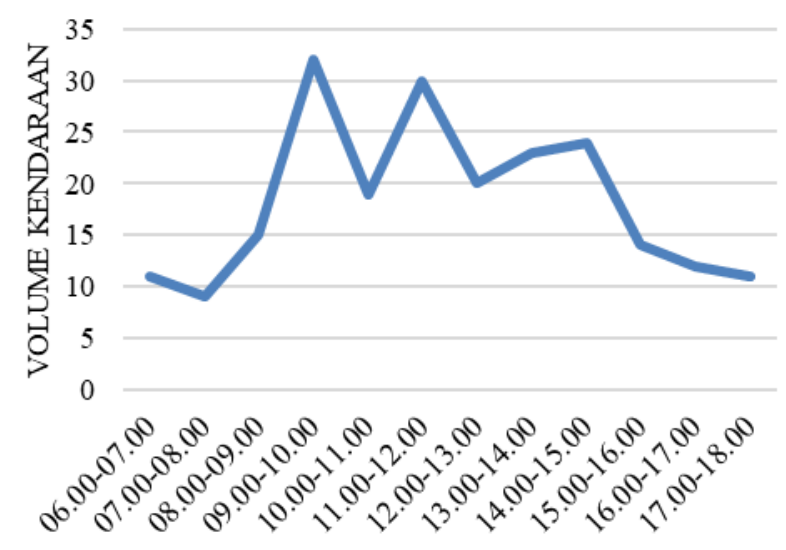

Gambar 10. Volume kendaraan engkel ganda 


\section{Kesimpulan}

Berdasarkan hasil pengolahan data dan analisis hasil maka kesimpulan dari hasil penelitian ini memperlihatkan bahwa persentase kendaraan Engkel Tunggal sebesar 2,68\%, kendaraan Engkel Ganda sebesar 84\%, kendaraan Trintin sebesar $0 \%$, kendaraan Tronton sebesar $12,64 \%$ dan kendaraan Trintin sebesar 0,26\%.

Volume Engkel Ganda merupakan jenis truk yang mendominasi kendaraan truk yang melewati jalan Poros Malino Gowa yaitu 84\%. Volume kendaraan Engkel Ganda tertinggi melewati jalan Poros Malino yaitu pada pukul 09.00 - 10.00 dengan jumlah sebanyak 32 kendaraan dan Volume kendaraan Engkel Ganda terendah melewati jalan tersebut yaitu pada pukul $07.00-$ 08.00 dan pukul 16.00-17.00 dengan jumlah sebanyak 13 kendaraan.

Hasil-hasil pada studi ini telah memberikan gambaran awal terhadap estimasi komposisi truk pada ruas jalan Poros Malino Gowa, dan lebih jauh dapat digunakan untuk menentukan jenis kendaraan truk dan waktu pengambilan data saat pagi, siang, dan sore hari pada studi emisi truk secara dinamis yang akan dilakukan pada studistudi lanjutan di masa mendatang.

\section{Ucapan Terimakasih}

Ucapan terima kasih, yang sebesar-besarnya atas dukungan Kementerian Riset dan Teknologi Dikti, Universitas Muhammadiyah Luwuk, Universitas Hasanuddin Makassar dan Koordinator Perguruan Tinggi Swasta (Kopertis) Wilayah IX di Makassar. Ucapan terima kasih juga penulis sampaikan kepada semua pihak yang ikut membantu dalam pelaksanaan penelitian ini.

\section{Referensi}

[1] Lutfie, M., Samang, L., Sakti A, Ramli, I. 2014. Analisis Komposisi Truk Pada Jaringan Jaringan Jalan Perkotaan Di Kota Makassar. Prosiding, $17^{\text {th }}$ FSTPT International Symposium Jember University, 22-24 Agustus 2014. Jember, Indonesia. Hal. 394-404

[2] https://id.wikipedia.org/wiki/Truk

[3] Sugiyono. 2009. Statistika Untuk Penelitian. Bandung: Penerbit Alfabeta. 